\title{
ANTIOXIDANT ACTIVITY OF OLIVE LEAF, POMACE AND VIRGIN OIL EXTRACTS FROM PICUAL CULTIVAR AND THEIR HEAT AND pH STABILITY
}

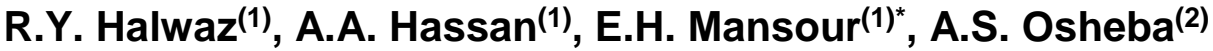 \\ and A.A. El-Bedawey(1)
}

(1) Department of Food Science and Technology, Faculty of Agriculture, Menoufia University, 32516 Shibin El-Kom, Egypt

(2) Meat and Fish Technology Research Department, Food Technology Research Institute, Agricultural Research Center, Giza, Egypt

${ }^{*}$ Corresponding author

E-mail:esam mansour@yahoo.com

Received: Jul. 3 , 2018

Accepted: Aug. 18, 2018

\begin{abstract}
Antioxidant activity of olive leaf, olive pomace and olive virgin oil as affected by ethanol, ethyl acetate and chloroform solvents were evaluated. Ethanol extracts of olive leaf and olive pomace as well as chloroform extract of olive virgin oil had higher antioxidant activity than those from other solvents. Leaf ethanol extract and $\alpha$-tocopherol had the similar antioxidant activity. Pomace ethanol extract had a higher ( $p$ $\leq 0.05)$ antioxidant activity than that of $\alpha$-tocopherol however; virgin oil chloroform extract had a lower $(p \leq 0.05)$ antioxidant activity than that of $\alpha$-tocopherol. Antioxidants of leaf ethanol extracts were heat-stable with retaining $67.04,74.15$, and $75.60 \%$ of its activity after dry heating at $100^{\circ} \mathrm{C}$ for $30 \mathrm{~min}$, boiling at $100^{\circ} \mathrm{C}$ for $35 \mathrm{~min}$ and autoclaving at $121^{\circ} \mathrm{C}$ for $30 \mathrm{~min}$, respectively. Antioxidants of pomace ethanol extracts were fairly heat-stable with $57.71,63.75,51.73 \%$ activity after dry heating at $100^{\circ} \mathrm{C}$ for $30 \mathrm{~min}$, boiling at $100^{\circ} \mathrm{C}$ for $35 \mathrm{~min}$ and autoclaving at $121^{\circ} \mathrm{C}$ for $30 \mathrm{~min}$, respectively. Antioxidant activities of leaf ethanol extract, pomace ethanol extract and virgin oil chloroform extract extracts were the maximum at $\mathrm{pH}$ 5.5. The induction periods of sunflower oil with $1 \%$ pomace ethanol extract, leaf ethanol extract and virgin oil chloroform extract were increased by 42.22, 35.56 and $16 \%$, respectively as compared with the control sunflower oil. Pomace ethanol extract and leaf ethanol extract might be promising sources of natural antioxidant to be used in food products.
\end{abstract}

Key words: Antioxidant activity, Olive fraction extracts, Heat stability, $\mathrm{pH}$ stability and Induction period

\section{INTRODUCTION}

The high levels of free radicals in living systems can oxidize biomolecules, leading to tissue damage, cell death, or various diseases such as skin irritations, degenerative processes associated with ageing, cardiovascular diseases, arteriosclerosis, diabetes, neural disorders, and cancer (Hadjaz et al., 2011; Jung et al., 2005; Trush et al., 1994). The antioxidant compound can deactivate and scavenge free radical by donating hydrogen atom or chelating metal. Therefore, commercial antioxidants are in high demand, and most of them are synthesized, including butylated hydroxyanisole (BHA), butylated hydroxytoluene (BHT) and propyl gallate (PG). However, these synthetic antioxidants are reported to be toxic and carcinogenic in animal models (El- Bedawey et al., 2010; Bouaziz et al., 2008; Mansour and Khalil, 2000). Thus, there is a growing request and interest on natural and safer antioxidants found in various kinds of land plants, such as 
cereals, vegetables, fruits and herbs; in which tocopherol, vitamin C, carotenoid, and polyphenols are good sources of antioxidant (El-Bedawey et al., 2010; Hussen et al., 2009; Gardner et al., 2000; Mansour and Khalil, 2000).

Virgin olive oil is obtained using mechanical pressing without any treatment other than washing, decanting, centrifugation, and filtering (International Olive Oil Council, 2003). It is rich in phytochemicals such as phenolic compounds. (Sicari, 2017; Franco et al., 2014; Bendini et al., 2007). The production of olive oil is associated with the generation of large amounts of olive pomace. Olive pomace is a complex lignocellulosic material consisting mainly of olive stones, pulp residues and fruit skins (Nunes et al., 2016). Olive pomaces considered a rich source of phenolic compounds with a wide array of biological activities (Morsi et al., 2016). Olive leaves are a waste of the olive oil processing industry and represent a good source of phenolic compounds (Difonzo et al., 2018, 2017; Zeitoun et al., 2017).

On the other hand, olive virgin oil, olive pomace and olive leaves can be used to prepare phenolic-rich extracts, suitable for food use. The use of olive fraction extracts allows improving the shelf-life of foods. Moudache et al., (2017) and Hayes et al., (2011) reported that olive leave extract improves lipid stability in meat products. Jiménez et al., (2017) and Zribi et al. (2013) showed an antioxidant effect of olive leave extract in frying oil. In addition, different authors showed that olive leave extract exhibits significant antioxidant activity, which could enhance the oxidative stability of vegetable oils (Rahmanian et al., 2015; Kiritsakis et al., 2010; Bouaziz et al., 2008).

To the best of our knowledge there are no reports concerning the effect of different heat treatments and $\mathrm{pH}$ values on the antioxidant activity of olive leaves, pomace and virgin oil extracts. Therefore, this study was carried out to evaluate the effect of different solvent extractions on the antioxidant activity of olive leaves, pomace and virgin oil. The best solvent extracts of olive fractions which showed the highest antioxidant activities were selected for studying the heat and $\mathrm{pH}$ stabilities of their antioxidant. Sunflower oil oxidative stability by adding olive fraction extracts was also evaluated.

\section{MATERIALS AND METHODS}

\section{Materials}

Olive leaf, pomace and virgin oil

The ripe olive (Olea europaea L.) fruits and leaves of picual cultivar were obtained in season of 2014/2015 from Matrouh Farms, Marsa Matrouh, Egypt. The pomace and virgin oil were prepared in Matrouh factory and transported in ice boxes to the laboratory.

\section{Preparation of olive leaves and pomaces:}

Olive leaves and pomace were dried in an electric air draught oven (Nüve San. Malz, Model FN 500, Akyuri, Ankara, Turkey) at $40^{\circ} \mathrm{C}$ for $12 \mathrm{~h}$. The dried samples were ground using a laboratory electric mill (Braun, Model 2001DL, Germany) to pass through a 60 mesh sieve and stored in screw cap plastic containers at $4^{\circ} \mathrm{C}$.

\section{Preparation of olive leaf, pomace and virgin oil extracts}

Fifty grams of olive leaf, pomace and virgin oil were extracted three times with $500 \mathrm{ml}$ of each solvent (ethanol 97\%, ethyl acetate 97\%, and chloroform 97\%) using a Teflon- coated magnetic stir bar and stir plate (Framo-Geratetechnik, Germany) for $6 \mathrm{~h}$ at room temperature. Extracts were filtrated through Whatman No. 1. The combined filtrates from each material were concentrated in a rotary 
evaporator (Laboratory 4000; Heidolph Instruments GmbH \& Co. KG, Germany) at $40^{\circ} \mathrm{C}$ to a final volume of $100 \mathrm{ml}$ of crude extracts and stored at $-20^{\circ} \mathrm{C}$ until used.

\section{Analytical methods \\ Determination of antioxidant activity \\ Antioxidant activity was determined} using the 2,2-dipheny-l-1picrylhydrazyl (DPPH) radical scavenging method according to the procedure described by Brand-Williams et al. (1995). Fifty $\mu \mathrm{l}$ from each extract (stock solution was 20.0 g/liter) was placed in a cuvette, and $2 \mathrm{ml}$ of $6 \times 10^{-5} \mathrm{M}$ methanol solution of DPPH was added. Absorbance was measured immediately at $517 \mathrm{~nm}$ (UNICO 2802 CIPCS Series Spectrophotometer, USA). The decrease in absorbance was measured every $5 \mathrm{~min}$ for $1 \mathrm{~h}$. Alphatocopherol was used for comparative purposes. The absorbance of the DPPH radical without antioxidant (control) was measured daily. Special care was taken to minimize the loss of free radical activity of the DPPH radical stock solution (Blois, 1958). The percentage of inhibition of the DPPH radical by the extracts (antioxidant activity) was calculated according to the equation of Yen and Duh (1994):

$\%$ inhibition $=\left[\left(A C(0) 517-A A(t){ }_{517}\right) \div\right.$ $\left.A C(0))_{517}\right] \times 100$

Where: $A C(0) 517$ is the absorbance of the control at $\mathrm{t}=0 \mathrm{~min}$.

AA ( $t$ ) 517 is the absorbance of the antioxidant at $\mathrm{t}=1 \mathrm{~h}$

Factors affecting the antioxidant activities stability of olive fraction extracts

The antioxidant activities stability of olive fraction extracts were determined as described by Mansour and Khalil (2000) as follows:

Dry heat stability of olive fraction extracts
Olive fraction extracts were preincubated in dry heating at different temperatures $(40,60,80,100){ }^{\circ} \mathrm{C}$ for 30 $\min$. The residual antioxidant activity was determined as previously mentioned.

\section{Boiling stability of olive fraction extracts}

Olive fraction extracts were boiled in water bath for $0,15,25,35,45$ and 60 $\mathrm{min}$. The residual antioxidant activity was determined as previously mentioned.

\section{Autoclaving stability of olive fraction extracts \\ Olive fraction extracts were} autoclaved at $121^{\circ} \mathrm{C}$ and Pressure 1.5 Bar for $0,15,20,25,30,35$ and $40 \mathrm{~min}$. The residual antioxidant activity was determined as previously mentioned.

\section{pH stability of olive fraction extracts}

Olive fraction extracts were preincubated at $\mathrm{pH}$ values in the range of $\mathbf{4 . 0}$ $-\mathbf{8 . 0}$ for $\mathbf{3 0} \mathrm{min}$. The residual antioxidant activity was determined as previously mentioned.

\section{Induction periods of sunflower oil containing different levels of olive fraction extracts}

The olive fraction extracts (leaf ethanol extract, pomace ethanol extract and virgin oil chloroform extract) and $\alpha$ tocopherol was added to sunflower oil at the concentrations of $0,0.5,1,2$ and $3 \%$. The mixture was kept at $40^{\circ} \mathrm{C}$ for $30 \mathrm{~min}$ and then in vacuum rotary evaporator (Buchi 011, Buchi, Switzerland) below $40^{\circ} \mathrm{C}$ for $1 \mathrm{~h}$ to complete removal of the solvent. A 679 Rancimat (Metrohm, Herisan, Switzerland) was used. Five grams from each test sample were loaded into the reaction vessel cylinder. Six different samples were conducted in one batch. The air supply was maintained at $20 \mathrm{ml} / \mathrm{min}$ and the heating temperature kept at $100^{\circ} \mathrm{C}$ throughout the experiment 
as described by Antolovich et al. (2002). The induction period (h) was recorded automatically.

\section{Statistical analysis:}

Data are presented as mean \pm SD (standard deviations). The comparison between antioxidant activity of the best solvent of olive fraction extracts and $\alpha$ tocopherol was analyzed using one-way analysis of variance. Two-way randomized blocks design was used for the other data. An analysis of variance was conducted using Costat version 6.311 (Copyright 1998-2005, CoHort software). When a significant main effect was detected, the means were separated with the Student Newman Keuls test. The predetermined acceptable level of probability was $5 \% \quad(\mathrm{P} \leq 0.05)$ for all comparisons.

\section{RESULTS AND DISCUSSION}

Antioxidant activities of olive fraction extracts

Antioxidant activities of olive as affected by olive fractions and solvent type were presented in Table (1). Picual olive leaf extracts had higher $(p \leq 0.05)$ mean antioxidant activity (70.29\%) than Picual olive pomace extracts (44.16\%) and Picual virgin oil extracts (41.82\%). Ethanol extract had higher $(p \leq 0.05)$ mean antioxidant activity (66.06\%) than chloroform extract (49.75\%) and ethyl acetate extract $(40.47 \%)$. This effect might be attributed to the solvent polarity index. Ethanol was the best solvent to extract responsible compounds for the antioxidant effect from olive leaf (79.35\%) and olive pomace (93.45\%), however chloroform was the best solvent for olive virgin oil (78.37\%). Antioxidant activity value of olive leaf ethanol extracts was $79.35 \%$ lower than the values (82.1 and 87.9\%) reported by Zeitoun et al. (2017) and Sheikh and Gabr (2016), respectively for olive leaf ethanol extract. Antioxidant activity of pomace ethanol extract (93.45\%) was comparable with the value (95.83\%) reported by Mohamed (2009) for olive pomace ethyl acetate extract. However, much lower values (14.06$57.50 \%$ ) were reported by EL-Shemy (2014) for olive pomace ethanol extract. Antioxidant activity of virgin oil chloroform extracts (78.37\%) was lower than the value $(97.86 \%)$ reported by Mohamed (2009) for virgin oil ethyl acetate extract, but, much higher than the values (14.8-26.6\%) reported by Franco et al. (2014) for virgin oil methanol extract. This difference might be due to the interspecies variation, solvent type and or the methods of antioxidant activity determination.

Table (1): Antioxidant activity of picual olive as affected by olive fraction and solvent types

\begin{tabular}{lcccc}
\hline Solvent types & \multicolumn{3}{c}{ Olive fractions } & \multirow{2}{*}{ Means $^{1}$} \\
\cline { 2 - 4 } & Leaf & Pomace & Virgin oil \\
\hline Ethanol & $79.35 \pm 0.51$ & $93.45 \pm 0.76$ & $25.37 \pm 0.24$ & $66.06^{\mathrm{a}}$ \\
Ethyl acetate & $75.02 \pm 0.72$ & $24.66 \pm 1.18$ & $21.74 \pm 0.19$ & $40.47^{\mathrm{c}}$ \\
Chloroform & $56.50 \pm 0.52$ & $14.37 \pm 1.57$ & $78.37 \pm 1.23$ & $49.75^{\mathrm{b}}$ \\
Means $^{2}$ & $70.29^{\mathrm{a}}$ & $44.16^{\mathrm{b}}$ & $41.82^{\mathrm{c}}$ & \\
\hline
\end{tabular}

(1) Means in the same column with different letters are significantly different (PS0.05), LSD $=0.81$

(2) Means in the same row with different letters are significantly different ( $P \leq 0.05), L S D=0.68$ 
Antioxidant activities of the best solvent extracts of olive fractions compared to a-tocopherol were presented in Table (2). Pomace ethanol extract $(93.45 \%)$ had higher ( $p \leq 0.05$ ) antioxidant activity than $\alpha$-tocopherol $(80.40 \%)$ and other olive fraction extracts. Alpha-tocopherol had higher ( $p \leq 0.05)$ antioxidant activity than virgin oil chloroform extract. Non-significant $(p>$ 0.05) difference in antioxidant activity was observed between leaf ethanol extract $(79.35 \%)$ and $\alpha$-tocopherol $(80.40 \%)$ and between leaf ethanol extract (79.35\%) and virgin oil chloroform extract (78.37\%). El-Bedawey et al., (2010) reported that ginger roots petroleum ether extract, orange peel, and guava leaf ethanol extracts exhibited higher antioxidant activities than that of $\alpha$ tocopherol while, guava seeds, sesame coat ethanol extracts had lower antioxidant activity compared to $\alpha$ tocopherol.

\section{*The best extracts which selected bassed on its antioxidant property. \\ Factors affecting the antioxidant activities stability of olive fraction extracts}

\section{Dry heat stability of olive fraction extracts}

Antioxidant activities of olive fractions as affected by dry heating at $40-100^{\circ} \mathrm{C}$ for 30 min were presented in Table (3). The mean antioxidant activities of pomace ethanol extracts $(67.05 \%)$ followed by leaf ethanol extracts $(61.36 \%)$ were more $(p \leq$ 0.05 ) stable than virgin oil chloroform extracts $(43.20 \%)$ when heated at 40 $100^{\circ} \mathrm{C}$ for $30 \mathrm{~min}$. There was significant ( $p$ $\leq 0.05$ ) difference in antioxidant activities among dry heated olive fraction extracts. Increasing the dry heating from $40^{\circ} \mathrm{C}$ to $100^{\circ} \mathrm{C}$ resulted in a significant $(p \leq 0.05)$ decrease in the antioxidant activities of olive fraction extracts. The mean antioxidant activities of olive fraction extracts were reduced by $26.62,34.83$, 44.86 and $52.72 \%$ when dry heated at 40 , 60,80 and $100^{\circ} \mathrm{C}$, respectively as compared with unheated olive fraction extracts. Saleh (2017) found that antioxidant activity of chamomile water extract was reduced by $37.90 \%$ when dry heated at $80^{\circ} \mathrm{C}$ for $30 \mathrm{~min}$. El-Bedawey et al. (2010) found that heating ginger roots extract at $100^{\circ} \mathrm{C}$ for $30 \mathrm{~min}$ reduced the antioxidant activity by $18.1 \%$. However, Mansour and Khalil (2000) reported a higher reduction value $(25 \%)$ for ginger roots.

Table (2): Antioxidant activity of the best solvent extracts of picual olive fractions compared to a-tocopherol

Olive fraction extracts

Antioxidant activity (\%)

Leaf ethanol extract

Pomace ethanol extract

Virgin oil chloroform extract

Alpha-tocopherol $(0.02 \mathrm{~g} / 10 \mathrm{ml}$ methanol 97\%) $79.35^{b c} \pm 0.51$

$93.45^{a} \pm 0.76$

$78.37^{c} \pm 1.23$

$80.40^{b} \pm 0.65$

1.23

Means in the same column with different letters are significantly different $(p \leq 0.05)$ 
R.Y. Halwaz, et al.,

Table (3): Effect of dry heating at $40-100^{\circ} \mathrm{C}$ for $30 \mathrm{~min}$ on antioxidant activities (\%) of picual olive fraction extracts

\begin{tabular}{|c|c|c|c|c|}
\hline \multirow[t]{2}{*}{$\left({ }^{\circ} \mathrm{C}\right)$} & \multicolumn{2}{|c|}{ Ethanol extract } & \multirow{2}{*}{$\begin{array}{c}\begin{array}{c}\text { Chloroform } \\
\text { extract }\end{array} \\
\text { virgin oil }\end{array}$} & \multirow[t]{2}{*}{ Means $^{1}$} \\
\hline & leaf & pomace & & \\
\hline unheated & $79.35 \pm 0.52$ & $93.95 \pm 0.76$ & $78.37 \pm 1.23$ & $83.89^{a}$ \\
\hline 40 & $60.58 \pm 1.19$ & $67.74 \pm 1.13$ & $56.35 \pm 0.95$ & $61.56^{b}$ \\
\hline 60 & $58.19 \pm 0.32$ & $60.19 \pm 0.82$ & $45.62 \pm 0.77$ & $54.67^{c}$ \\
\hline 80 & $55.50 \pm 0.71$ & $59.17 \pm 1.26$ & $24.12 \pm 1.25$ & $46.26^{d}$ \\
\hline 100 & $53.20 \pm 0.31$ & $54.22 \pm 0.29$ & $11.56 \pm 0.73$ & $39.66^{\mathrm{e}}$ \\
\hline Means $^{2}$ & $61.36^{b}$ & $67.05^{a}$ & $43.20^{c}$ & \\
\hline
\end{tabular}

\section{Boiling stability of olive fraction extracts}

Antioxidant activities of olive fractions as affected by boiling at $100^{\circ} \mathrm{C}$ for different times were presented in Table (4). The mean antioxidant activities of pomace ethanol extracts (65.34\%) followed by leaf ethanol extracts $(61.83 \%)$ were more ( $p \leq 0.05)$ stable than virgin oil chloroform extracts $(58.01 \%)$ when boiled at $100^{\circ} \mathrm{C}$ for $15-60 \mathrm{~min}$. There was significant ( $p \leq 0.05)$ difference in antioxidant activities among boiled olive fraction extracts for different times. Increasing the boiling time from 15 to 60 min resulted in a significant ( $p \leq 0.05)$ decrease in the antioxidant activities of olive fraction extracts. The mean antioxidant activities of olive fraction extracts were reduced by $23.11,28.38$, $30.78,33.87$ and $42.38 \%$ when boiled for $15,25,35,45$ and $60 \mathrm{~min}$, respectively as compared with unboiled olive fraction extracts. The similar reduction in antioxidant activity by boiling treatment was reported by Reddy et al. (2014b) who found that the radical scavenging activity of Canthium parviflorum leaf extract was reduced from by $41.18 \%$ when boiled at $100^{\circ} \mathrm{C}$ for $30 \mathrm{~min}$. El-Bedawey et al. (2010) reported that boiling ginger root, guava leaf, guava seed, orange peel, sesame coat, rice bran and wheat germ extracts at $100^{\circ} \mathrm{C}$ for $60 \mathrm{~min}$ reduced the antioxidant activities by $22.97,20,66.78$, $41.47,20.51, \quad 39.21$ and $57.26 \%$, respectively. Hussein et al. (2009) reported that boiling ginger root, canola seed, soybean, and fenugreek seed extracts at $100^{\circ} \mathrm{C}$ for 60 min reduced the antioxidant activities by $37.41,48.09$, 35.68 and $41.46 \%$, respectively. Mansour and Khalil (2000) found that boiling ginger root, fenugreek seed, and potato peel extracts at $100^{\circ} \mathrm{C}$ for $120 \mathrm{~min}$ reduced the antioxidant activity by 72,42 and $36.8 \%$, respectively. The opposite results were reported by Reddy et al. (2014a) who found that boiling of Abrus precatorius leaf extract at $100^{\circ} \mathrm{C}$ for 30 min resulted in an increase of radical scavenging activity by $53.57 \%$.

\section{Autoclaving stability of olive fraction extracts}

Antioxidant activities of olive fractions as affected by autoclaving at $121^{\circ} \mathrm{C}$ for different times were presented in Table (5). The mean antioxidant activities of pomace ethanol extracts (63.51\%) followed by leaf ethanol extracts $(62.02 \%)$ were more $(p \leq 0.05)$ stable than virgin oil 
chloroform extracts (54.37\%) when autoclaved at $121^{\circ} \mathrm{C}$ for different times. There was significant $(p \leq 0.05)$ difference in antioxidant activities among autoclaved olive fraction extracts. Antioxidant activities of olive fraction extracts were significant ( $p \leq 0.05)$ decreased by increasing the autoclaving times from 15 to $40 \mathrm{~min}$. The mean antioxidant activities of olive fraction extracts were reduced by $15.19,23.52$, $32.93,38.56,43.01$ and $46.35 \%$ when autoclaved at $121^{\circ} \mathrm{C}$ for $15,20,25,30,35$ and $40 \mathrm{~min}$, respectively as compared with unautoclaved olive fraction extracts. The comparable reduction in antioxidant activities was mentioned above for boiled olive fraction extracts (Table 4) and Reddy et al. (2014b) for boiled Canthium parviflorum leaf extract for $30 \mathrm{~min}$.

Table (4): Effect of boiling for different times on antioxidant activities (\%) of picual olive fraction extracts

\begin{tabular}{|c|c|c|c|c|}
\hline \multirow[t]{2}{*}{ Time (min) } & \multicolumn{2}{|c|}{ Ethanol extract } & \multirow{2}{*}{$\begin{array}{c}\begin{array}{c}\text { Chloroform } \\
\text { extract }\end{array} \\
\text { virgin oil }\end{array}$} & \multirow[t]{2}{*}{ Means $^{1}$} \\
\hline & leaf & pomace & & \\
\hline unboiled & $79.35 \pm 0.52$ & $93.95 \pm 0.77$ & $78.37 \pm 1.23$ & $83.89^{a}$ \\
\hline 15 & $62.80 \pm 0.46$ & $70.53 \pm 0.08$ & $60.16 \pm 0.06$ & $64.50^{b}$ \\
\hline 25 & $59.14 \pm 0.02$ & $61.66 \pm 0.15$ & $59.45 \pm 0.09$ & $60.08^{c}$ \\
\hline 35 & $58.84 \pm 0.06$ & $5^{9} .89 \pm 0.02$ & $55.48 \pm 0.02$ & $58.07^{d}$ \\
\hline 45 & $58.10 \pm 0.26$ & $54.48 \pm 1.52$ & $53.86 \pm 0.02$ & $55.48^{e}$ \\
\hline 60 & $52.74 \pm 0.05$ & $\bullet 1.52 \pm 0.05$ & $40.75 \pm 0.07$ & $48.34^{f}$ \\
\hline Means $^{2}$ & $61.83^{b}$ & $65.34^{\mathrm{a}}$ & $58.01^{c}$ & \\
\hline
\end{tabular}

Table (5): Effect of autoclaving at $121^{\circ} \mathrm{C}$ for different times on antioxidant activities (\%) of picual olive fraction extracts

\begin{tabular}{|c|c|c|c|c|}
\hline \multirow[t]{2}{*}{ Time (min) } & \multicolumn{2}{|c|}{ Ethanol extract } & \multirow{2}{*}{$\begin{array}{c}\begin{array}{c}\text { Chloroform } \\
\text { extract }\end{array} \\
\text { virgin oil }\end{array}$} & \multirow[t]{2}{*}{ Means $^{1}$} \\
\hline & leaf & pomace & & \\
\hline unautoclaved & $79.35 \pm 0.52$ & $93.95 \pm 0.77$ & $78.37 \pm 1.23$ & $83.89^{a}$ \\
\hline 15 & $65.40 \pm 0.90$ & $84.16 \pm 0.74$ & $63.84 \pm 0.90$ & $71.13^{b}$ \\
\hline 20 & $64.30 \pm 0.45$ & $67.02 \pm 0.66$ & $61.10 \pm 0.87$ & $64.14^{c}$ \\
\hline 25 & $59.30 \pm 1.08$ & $58.05 \pm 0.91$ & $51.40 \pm 0.90$ & $56.25^{d}$ \\
\hline 30 & $59.20 \pm 0.33$ & $48.60 \pm 0.94$ & $46.80 \pm 1.18$ & $51.53^{e}$ \\
\hline 35 & $53.80 \pm 0.80$ & $47.00 \pm 0.54$ & $42.60 \pm 0.58$ & $47.80^{f}$ \\
\hline 40 & $52.80 \pm 0.17$ & $45.70 \pm 0.17$ & $36.50 \pm 0.50$ & $45.00^{\mathrm{g}}$ \\
\hline Means $^{2}$ & $62.02^{b}$ & $63.51^{\mathrm{a}}$ & $54.37^{c}$ & \\
\hline
\end{tabular}


pH stability of olive fraction extracts

Antioxidant activities of olive fractions as affected by different $\mathrm{pH}$ were presented in Table (6). Antioxidant activities of olive fraction extracts were varied ( $p \leq 0.05)$ with the $\mathrm{pH}$ values. The mean antioxidant activities of pomace ethanol extracts $(77.53 \%)$ followed by leaf ethanol extracts $(70.71 \%)$ were more $(p \leq$ 0.05 ) stable than virgin oil chloroform (63.73\%) when treated with different $\mathrm{pH}$ values. The antioxidant activity of olive fraction extracts gradually increased $(p \leq$ $0.05)$ till pH 5.5 followed by a continuous decrease $(p \leq 0.05)$. The mean antioxidant activities of olive fraction extracts were increased by $5.61 \%$ at $\mathrm{pH} 5$ and $8.42 \%$ at pH 5.5. However, at pH 6, 6.5, 7 and 8, antioxidant activities of olive fraction extracts were reduced by $9.12,20.16$, 27.84 and $37.51 \%$, respectively. The reduction of antioxidant activity at alkaline $\mathrm{pH}$ might be attributed to either the loss of antioxidant property of the extracts or the enhancement of lipid oxidation (Mansour and Khalil 2000). Hussein et al. (2009) reported that the antioxidant activity of ginger root extracts increased with $\mathrm{pH}$ between 5 and 7.

Induction periods of sunflower oil containing different levels of olive fraction extracts and $\alpha$-tocopherol
Induction periods of sunflower oil containing different levels of olive fraction extracts and $\alpha$-tocopherol were presented in Table (7). Sunflower oil containing different levels of olive fraction extracts had higher ( $p \leq 0.05$ ) induction period than the control sunflower oil. The highest ( $p \leq 0.05$ ) induction period of sunflower oil was obtained by the addition of $1 \%$ followed by $2 \%$ olive fraction extracts. The $\alpha$ tocopherol $(8.31 \mathrm{~h})$ had a higher $(\mathrm{p} \leq 0.05)$ mean induction period than all olive $(4.85-5.39$ h) fraction extracts. Nonsignificant $(p>0.05)$ difference was observed in induction period between pomace ethanol extract $(5.39 \mathrm{~h})$ and leaf ethanol extract $(5.28 \mathrm{~h})$. At $1 \%$ level, the antioxidant potential of leaf ethanol extract, pomace ethanol extract and virgin oil chloroform extract were 63.21, 66.32 and $54.09 \%$, respectively compared to a-tocopherol. The induction periods of sunflower oil with $1 \%$ leaf ethanol extract, pomace ethanol extract and virgin oil chloroform extract were increased by $35.56,42.22$ and $16 \%$, respectively as compared with the control sunflower oil. Morsi et al. (2016) reported that addition of olive pomace extract at concentration of $150 \mathrm{mg}$ gallic acid/kg oil increased sunflower oil oxidative stability by $36 \%$ in comparison with the control sample. Lafka et al. (2013) reported that olive leaf ethanol extracts increased the induction time of sunflower oil by $74.09 \%$.

Table (6): Effect of different pH on antioxidant activities (\%) of picual olive fraction extracts

\begin{tabular}{|c|c|c|c|c|}
\hline \multirow[t]{2}{*}{$\mathrm{pH}$} & \multicolumn{2}{|c|}{ Ethanol extract } & \multirow{2}{*}{$\begin{array}{c}\begin{array}{c}\text { Chloroform } \\
\text { extract }\end{array} \\
\text { virgin oil }\end{array}$} & \multirow[t]{2}{*}{ Means $^{1}$} \\
\hline & leaf & pomace & & \\
\hline 4 & $76.10 \pm 0.04$ & $90.89 \pm 0.04$ & $72.57 \pm 0.01$ & $79.85^{c}$ \\
\hline 5 & $87.47 \pm 0.09$ & $92.04 \pm 0.01$ & $73.47 \pm 0.01$ & $84.33^{b}$ \\
\hline 5.5 & $88.14 \pm 0.01$ & $93.45 \pm 0.19$ & $78.13 \pm 0.03$ & $86.57^{a}$ \\
\hline 6 & $79.13 \pm 0.03$ & $78.29 \pm 0.02$ & $60.28 \pm 0.11$ & $72.57^{d}$ \\
\hline 6.5 & $65.00 \pm 0.04$ & $67.74 \pm 0.03$ & $58.50 \pm 0.09$ & $63.75^{e}$ \\
\hline 7 & $57.70 \pm 0.05$ & $61.29 \pm 0.03$ & $53.86 \pm 0.01$ & $57.62^{f}$ \\
\hline 8 & $41.40 \pm 0.01$ & $59.03 \pm 0.03$ & $49.28 \pm 0.01$ & $49.90^{\mathrm{g}}$ \\
\hline Means $^{2}$ & $70.71^{b}$ & $77.53^{\mathrm{a}}$ & $63.73^{c}$ & \\
\hline
\end{tabular}

${ }^{1}$ Means in the same column with different letters are significantly different $(p \leq 0.05)$, LSD $=0.06$

${ }^{2}$ Means in the same row with different letters are significantly different $(p \leq 0.05), L S D=0.04$ 
Table (7): Induction period (h) of sunflower oil containing different levels of picual olive fraction extracts and $\alpha$-tocopherol

\begin{tabular}{lcccccc}
\hline \multirow{2}{*}{ Extract types } & \multicolumn{5}{c}{ Olive fraction extracts levels (\%) } & \multirow{2}{*}{ Means $^{1}$} \\
\cline { 2 - 6 } & 0 & 0.5 & 1 & 2 & 3 & \\
\hline Leaf ethanol extract & 4.50 & 5.33 & 6.10 & 5.43 & 5.02 & $5.28^{\mathrm{b}}$ \\
& \pm 0.26 & \pm 0.13 & \pm 0.30 & \pm 0.05 & \pm 0.12 & \\
Pomace ethanol extract & 4.50 & 5.60 & 6.40 & 5.86 & 4.57 & $5.39^{\mathrm{b}}$ \\
& \pm 0.26 & \pm 0.14 & \pm 0.09 & \pm 0.02 & \pm 0.02 & \\
Virgin oil chloroform extract & 4.50 & 4.99 & 5.22 & 5.01 & 4.55 & $4.85^{\mathrm{c}}$ \\
& \pm 0.26 & \pm 0.08 & \pm 0.26 & \pm 0.02 & \pm 0.05 & \\
Alpha-tocopherol (0.02g /10 & 4.50 & 8.60 & 9.65 & 9.68 & 9.10 & $8.31^{\mathrm{a}}$ \\
ml methanol 97\%) & \pm 0.26 & \pm 0.10 & \pm 0.13 & \pm 0.03 & \pm 0.10 & \\
Means $^{2}$ & $4.50^{\mathrm{e}}$ & $5.96^{\mathrm{c}}$ & $6.62^{\mathrm{a}}$ & $6.34^{\mathrm{b}}$ & $5.76^{\mathrm{d}}$ & \\
\hline
\end{tabular}

${ }^{1}$ Means in the same column with different letters are significantly different $(p \leq 0.05)$, LSD $=0.12$

${ }^{2}$ Means in the same raw with different letters are significantly different $(p \leq 0.05), L S D=0.09$

\section{CONCLUSION}

From the above results, it could be concluded that leaf ethanol extract, pomace ethanol extract and virgin oil chloroform extract are potential source of antioxidants which are responsible for the antioxidant activity. The induction periods of sunflower oil with $1 \%$ leaf and pomace ethanol extracts were increased by 35.56 and $42.22 \%$, respectively as compared with the control sunflower oil. The stability to heat and $\mathrm{pH}$ of the different olive fraction extracts with strong antioxidant activity indicates their scope for utilization in food and biological systems.

\section{REFERENCES}

Antolovich, M., P. D. Prenzler, E. Patsalides, S. Mcdonald and K. Robards (2002). Methods for testing antioxidant activity. Critical Review. The Analyst (The Royal Society of Chemistry), 127: 186-198.

Bendini, A., L. Cerretani, A. CarrascoPancorbo, A.M. Gómez-Caravaca, A.
Segura-Carretero, A. FernándezGutiérrez and G. Lercker (2007). Phenolic molecules in virgin olive oils: a survey of their sensory properties, health effects, antioxidant activity and analytical methods. An over view of the last decade. Molecules, 12, 16791719.

Blois, M. S. (1958). Antioxidant determinations by the use of a stable free radical. Nature, 181, 1199-1200.

Bouaziz, M., I. Fki, H. Jemai, M. Ayadi and S. Sayadi (2008). Effect of storage on refined and husk olive oils composition: Stabilization by addition on atural antioxidants from Chemlali olive leaves. Food Chemistry, 108, 253-262.

Brand-Williams, W., M. E. Cuvelier and C. Berset (1995). Use of a free radical method to evaluate antioxidant activity. Lebensmitttel Wissenschaft und Technologie, 28, 25-30.

Difonzo, G., A. Pasqualone, R. Silletti, L. Cosmai, C. Summo, V. M. Paradiso and F. Caponio (2018). Use of olive 
leaf extract to reduce lipid oxidation of baked snacks. Food Res. Int., 108, 4856.

Difonzo, G., A. Russo, A. Trani, V. M. Paradiso, M. Ranieri, A. Pasqualone, C. Summo, G. Tamma, R. Silletti and F. Caponio (2017). Green extracts from Coratina olive cultivar leaves: Antioxidant characterization and biological activity. Journal of Functional Foods, 31, 63-70.

El-Bedawey, A. A., E. H. Mansour, M. S. Zaky and A. H. Amal (2010). Characteristics of antioxidant isolated from some plant sources. Food and Nutrition Sciences, 1, 5-12.

El-Shemy, S. M. E. (2014). Chemical and technological studies on olive and tomato wastes treated by gamma irradiation. Ph. D. dissertation, University of Banha, Egypt.

Franco, M. N., T. Galeano-Díaz, Ó. López, J. G. Fernández-Bolaños, J. Sánchez, C. De Miguel, M. V. Gil and D. MartínVertedor (2014). Phenolic compounds and antioxidant capacity of virgin olive oil. Food Chem., 163, 289-298.

Gardner, P. T., T. A. C. White, D. B. McPhail and G. G. Duthie (2000). The relative contributions of vitamin $\mathrm{C}$, carotenoids and phenolics to the antioxidant potential of fruit juices. Food Chemistry, 68, 471-474.

Hadjaz, F., S. Besret, F. Martin-Nizard, S. Yous, S. Dilly, N. Lebegue, P. Chavatte, P. Duriez, P. Berthelot and P. Carato (2011). Antioxydant activity of $\beta$-carboline derivatives in the LDL oxidation model. Eur J Med Chemistry, 46, 2575-2585.

Hayes, J. E., V. Stepanyan, P. Allen, M. N. O'Grady and J. P. Kerry (2011). Evaluation of the effects of selected plant-derived nutraceuticals on the quality and shelf-life stability of raw and cooked pork sausages. LWT-Food Science and Technology, 44(1), 164172.
Hussein, E. A., E. H. Mansour and Naglaa, A. E. (2009). Antioxidant properties of solvent extracts from some plant sources. Annals of Agricultural Sciences. Ain Shams University, Cairo, Egypt, 54, 385-396.

International Olive Oil Council (2003). Trade standard applying to olive oils and olive-pomace oils.

Jiménez, P., P. García, A. Bustamante, A. Barriga and P. Robert (2017). Thermal stability of oils added with avocado (Persea americana cv. Hass) or olive (Olea europaea cv. Arbequina) leaf extracts during the French potatoes frying. Food Chemistry, 221, 123-129.

Jung, C. H., H. M. Seog, I. W. Choi, H. D. Choi and H. Y. Cho (2005). Effects of wild ginseng (Panax ginseng C.A. Meyer) leaves on lipid peroxidation levels and antioxidant enzyme activities in streptozotocin diabetic rats. J Ethnopharmacol, 98, 245-250.

Kiritsakis, K., M. G. Kontominas, C. Kontogiorgis, D. Hadjipavlou-Litina, A. Moustakas and A. Kiritsakis (2010). Composition and antioxidant activity of olive leaf extracts from Greek olive cultivars. Journal of the American Oil Chemists' Society, 87, 369-376.

Lafka, T. I., A. E. Lazou, V. J. Sinanoglou and E. S. Lazos (2013). Phenolic extracts from wild olive leaves and their potential as edible oils antioxidants. Journal of Foods, 2, 1831.

Mansour, E. H. and A. H. Khalil (2000). Evaluation of antioxidant activity of some plant extracts and their application to ground beef patties. Food Chemistry, 69, 135-141.

Mohamed, R. M. E. (2009). Evaluation of phenolic compounds of virgin olive oil cultivars and their pomace as natural antioxidants. M.Sc. dissertation, University of Cairo, Egypt.

Morsi, M. K. S., S. M. Galal and O. Alabdulla (2016). Antioxidative activity of olive pomace poly phenols 
obtained by ultrasound assisted extraction. Journal of Environmental Science, Toxicology and Food Technology, 10, 95-100.

Moudache, M., C. Nerín, M. Colon and F. Zaidi (2017). Antioxidant effect of an innovative active plastic film containing olive leaves extract on fresh pork meat and its evaluation by Raman spectroscopy. Food Chemistry, 229, 98-103.

Nunes, M. A., F. B. Pimentel, A. S. G. Costa, R. C. Alves and M. B. P. P. Oliveira (2016). Olive by-products for functional and food applications: Challenging opportunities to face environmental constraints. In novative Food Science and Emerging Technologies, 35, 139-148.

Rahmanian, N., S.M. Jafari and T.A. Wani (2015). Bioactive profile dehydration, extraction of the bioactive components of olive leaves. Trends food Sci.Technology, 42,150-172.

Reddy, V. P., S. Mahalingu and A. Urooj (2014a). Abrus precatorius leaves: antioxidant activity in food and biological Systems, $\mathrm{pH}$, and temperature stability. International journal of medicinal chemistry, 2014, 1-7.

Reddy, V. P., S. Mahalingu and A. Urooj (2014b). Canthium parviflorum leaves: Antioxidant activity in food and biological systems, $\mathrm{pH}$, and temperature stability. Chinese Journal of Biology, 2014, 1-7.

Saleh, M. B. (2017). Phytochemical and Pharmacological Investigation on
Phyllanthus Acid us Leaf. Ph. D. Thesis, Fac. of Agric., East West University, Dhaka, Bangladesh.

Sheikh, P. Y. and S. Gabr (2016). Influence of extraction solvents and phytochemical Analysis in the evaluation of in-vitro antioxidant activity of Saudi Arabian olive leaves extract. Journal of American Chemistry and Application, 3(2), 6 -12.

Sicari, V. (2017). Antioxidant potential of extra virgin olive oils extracted from three different varieties cultivated in the Italian province of Reggio Calabria. Journal of Applied Botany and Food Quality, 90, 76-82.

Trush, M., P. Egner and W. Kensler (1994). Myeloperoxidse as a biomarker of skin irritation and inflammation. Food Chem Toxicol, 32, 143-147.

Yen, G. C. and P. D. Duh (1994). Scavenging effect of methanolic extracts of peanut hulls on free-radical and active-oxygen species. Journal of Agriculture and Food Chemistry, 42, 629-632.

Zeitoun, M. A. M., H. M. M. Mansour, S. Ezzat and A. El Sohaimy (2017). Effect of pretreatment of olive leaves on phenolic content and antioxidant activity. Am. J. Food Technology, 12, 132-139.

Zribi, A., B. Gargouri, H. Jabeur, A. Rebaï, R. Abdelhedi and M. Bouaziz (2013). Enrichment of pan-frying refined oils with olive leaf phenolic-rich extract to extend the usage life. European Journal of Lipid Science and Technology, 115, 1443-1453. 


\section{النشاط المانع للأكسدة لمستخلصات أوراق الزيتون وتفلة الزيتون وزيت الزيتون البكر} لصنف البيكوال وثباتها للحرارة واليتون والحموضة لزيونة

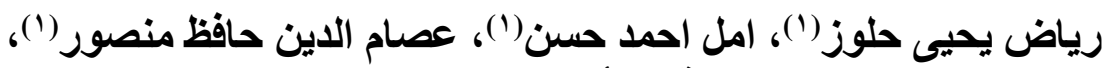

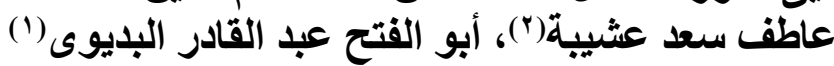

(1) قسم علوم و تكنولوجيا الأغذية، كلية الزراعة، جامعة المنوفية الفية

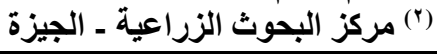

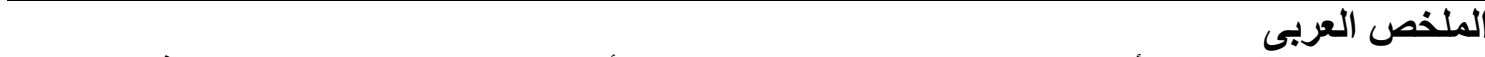

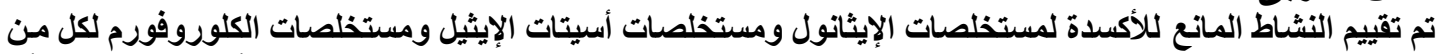

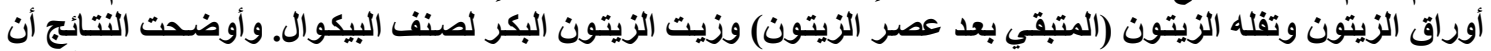

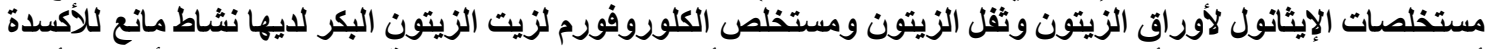

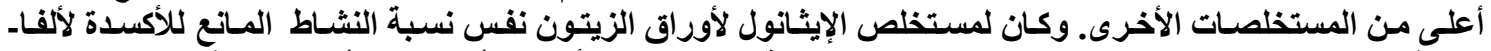

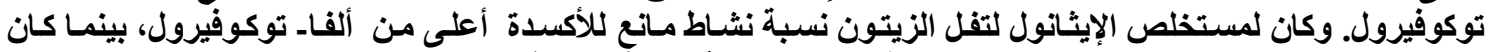

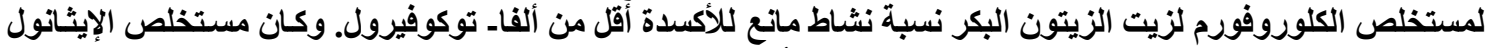

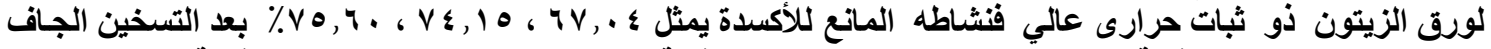

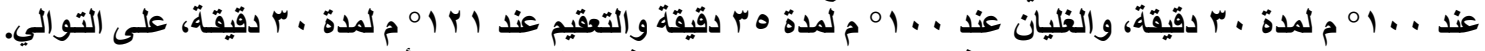

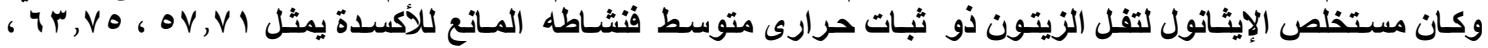

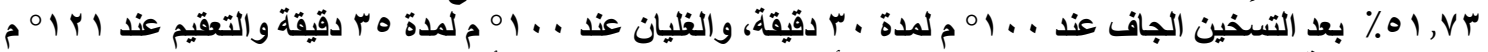

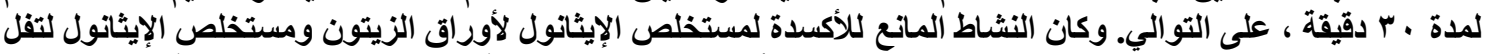

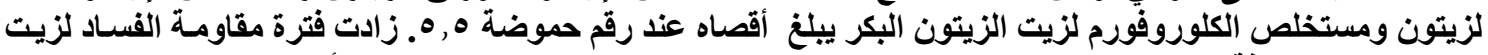

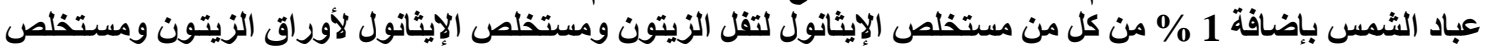

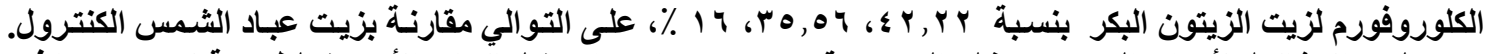

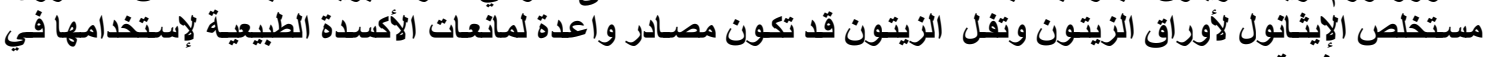
المنتجات الغذائية. الكلمات الدالة: النشاط المـاتع للأكسدة، مستخلصـات أجزاء الزيتون المختلفة، الثبات الحراري، الثبات لارجة الحموضـة

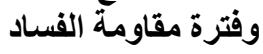

أسماء السادة المحكمين

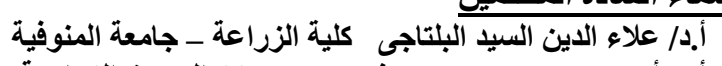

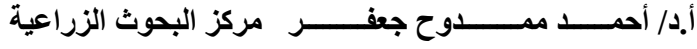


$\underline{\text { Antioxidant activity of olive leaf, pomace and virgin oil extracts from picual ......... }}$ 